\title{
Historein
}

Vol $11(2011)$

Politics and History

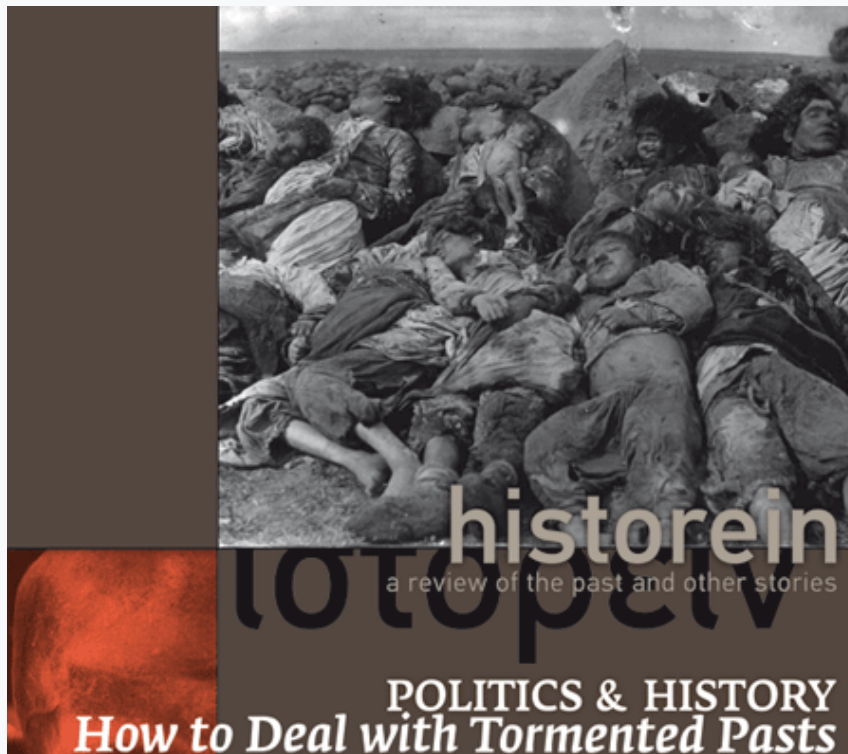

\section{Kulturgeschichte as a Political Tool: The Finnish} Case

Marja Jalava

doi: $10.12681 /$ historein.144

Copyright @ 2012, Marja Jalava

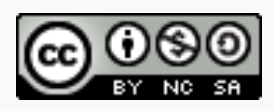

This work is licensed under a Creative Commons Attribution-NonCommercialShareAlike 4.0.

\section{Pierre Nora \\ Jörn Rüsen \\ Wolfgang Benz \\ Luigi Cajani \\ Antoon De Baets}

\section{To cite this article:}

Jalava, M. (2012). Kulturgeschichte as a Political Tool: The Finnish Case. Historein, 11, 125-135.

https://doi.org/10.12681/historein.144 
It has recently been suggested that the "social question" and a "liberal" social history, leaning towards social democracy early in the twentieth century, would have been able to successfully claim a role in national historiography only in cases where the nation-state could already look back on a long, continuous history, and where the state had remained uncontested in its geographical boundaries. This may have prepared the ground for a more tolerant atmosphere within the discipline of history.'

However, if we consider Europe's northern periphery, especially Finnish, Norwegian and Swedish historiographies at the turn of the twentieth century, we seem to find a rather opposite case. ${ }^{2}$ In Sweden, which had a long history as one of the great powers in Europe, the state continued to be the focus of attention, and the "social question" was mostly discussed outside the discipline of history. In Norway, however, which had an interrupted, discontinuous state history and in Finland, which had only limited political independence before 1917, academic historians were more receptive early on to alternatives to the dominant paradigm of individualistic, state-centric political history, and were eager to study such ideas as the German historian Karl Lamprecht's (1856-1915) Kulturgeschichte. ${ }^{3}$

The aim of this article is to discuss the early twentieth-century Finnish reception of Kulturgeschichte, with special reference to its domestic and foreign policy-related dimensions. The discussion is based on a conception of politics where "politics" is viewed as an activity arising from conditions of diver-

\section{Kulturgeschichte as \\ a Political Tool: The \\ Finnish Case}

\section{Marja Jalava}

University of Helsinki 
sity in which different groups press different claims and express different views concerning the supposed common good. ${ }^{4}$ Thus, in this case, "political history" is not limited to the field of academic history, which focuses on formal political processes, military actions and diplomatic manoeuvrings. Indeed, in principle, almost all phenomena in historiography can be politicised, in other words, reinterpreted from a political point of view, if historians and/or their audience choose to use history for the creation of something new, in possible opposition to some generally accepted "truths" and "givens". ${ }^{5}$

Closely related to the use of historical research as a political tool is its ideological utilisation to attain or maintain a particular social or political order. This notion of ideology, which Karl Mannheim called the "particular" conception of ideology, refers here to a collection of ideas which, typically, contains certain notions about what it considers to be the best form of government and the best economic system. ${ }^{6}$ For instance, in the case of the early "liberal-minded" social historians, the interest in economic and social structures was clearly connected to a favourable attitude towards the democratisation of the political system. Although an ideology is often pejoratively identified with a mere illusion, unreality or "false consciousness", the term is used here in a relatively neutral sense to emphasise the fact that history is never the past but always about the past; it is a translation of the past into the historian's own time and place, an act of interpretation in which representations and values as well as narrative and conceptual structures in language inevitably shape the very same subject he or she represents. Thus, while I am describing the Lamprechtian Kulturgeschichte as an ideological and political tool of certain Finnish historians, I am not suggesting a distinction between supposedly value-free academic history "proper" and some other schools of thought, such as Kulturgeschichte, as false ideologies. On the contrary, I consider all historical research to be positioned and positioning, for due to our corporeal being-in-the-world, there is no possibility of an unpositioned site. ${ }^{7}$ This was acknowledged by the Finnish Lamprechtians, too. To cite the social historian Väinö Voionmaa (1869-1947): "The emerging new conception of society unavoidably has an effect on the understanding of the past, for one has to seek the initial roots of the new development from the past." ${ }^{\text {"8 }}$

\section{The political role of history in an 'unhistorical' nation}

From a cross-European comparative perspective, the case of nation-building in Finland differed from most European small nations, such as the Czechs and the Catalans who were fighting for a separate state or autonomous status, for the Finnish state as a political unit (the Grand Duchy of Finland) was established in 1809 as an unintended, unasked consequence of the Napoleonic Wars. Among the educated elites of this former eastern province of the Swedish Empire, the new political situation gave rise to an identity crisis, since by and large they had considered themselves to be Swedes with the same rights and duties as subjects living west of the Gulf of Bothnia.?

While the 600-year-old ties with Sweden were broken once and for all, the issue of uppermost importance for the Finns as a nation and as individuals was "to become aware of the national individuality of Finland, to gain the self-knowledge of our inner state, and to develop our definite national character", as Johan Jakob Tengström (1787-1858), professor of philosophy at the Im- 
perial Alexander University of Finland (the present University of Helsinki), put it in the earliest public discussion on the matter, published in 1817-1818. ${ }^{10}$ However, as Tengström, a supporter of Hegelian philosophy, knew all too well, the constitution of a sovereign state was considered by G.W.F. Hegel a precondition for the existence of a people in the full historical sense of the word. Because of the lack of an independent political history before 1809, the Finns were in danger of becoming classified as an "unhistorical" nation, thereby not deserving of self-determination."

In order to legitimise the autonomy of Finland both from Sweden and Russia, similarly to other subaltern regions of Europe the Finnish nation-builders found the solution in an eclectic combination of Hegel and Herder. On the one hand, the nationally minded historians introduced the concepts of "Sweden-Finland" and "the period of Swedish rule", the former suggesting that the realm had actually been a dual monarchy, and the latter implying that Finland as a political unit had already existed before "the Swedish conquest". In both cases, one could extend the scope of the state-centric political history of Finland to the ancient past. ${ }^{12}$ On the other hand, however, much more importantly, Herder's cultural nationalism offered the axiom of ethnicity as the categorical starting point for the agenda of national emancipation. As the historian Frederick M. Barnard has emphasised, Herder's focus on a distinctive matrix of language and social culture as well as the ordinary people as the true foundations on which nationhood and statehood could be built did not involve a shift from the political to the nonpolitical or apolitical but rather a redefinition of the political itself and a radical reappraisal of its bases of legitimacy. Here national culture emerged as something not only potentially relevant to politics but as something indispensably necessary, which authorised a Kulturnation to stake a claim for its becoming a sovereign state. ${ }^{13}$

Thus, Johan Vilhelm Snellman (1806-1881), styled "the national philosopher of Finland" because of his role as the ideological leader of the emerging Finnish nationalist movement, argued in his major sociopolitical work Läran om staten [The study of the state, 1842] that a nation which had grown to self-awareness and was acting in accordance with the demands of its national spirit had reached a higher developmental stage than a sovereign state, such as multiethnic, multilingual Switzerland, where the national spirit as well as the inhabitants were "completely lethargic". ${ }^{14}$ In order to achieve this qualitative leap, the nation had to have a history of its own. In 1844 Snellman therefore insisted that Finnish historians inaugurate studies on social and cultural phenomena because the inner continuity of genuine Finnish history was, in his opinion, mainly to be found in the past of the Finnish people and not within governmental and administrative institutions. In Snellman's eyes, "the Finnish people" was not only or even primarily a folkloristic item, and instead he was especially interested in the history of the working classes (de arbetande klasserna), in other words, those tradespeople, industrialists and the proletariat that were formed by the emerging modern capitalist system and its accompanying civil liberties (medborgerlig frihet). ${ }^{15}$ Although the industrial revolution in Finland seemed to be an issue for the future, the examples of the most developed European countries (for Snellman, these included Britain, France and Germany) had proved to him that the problem of national unity had to be considered in a socioeconomic light. ${ }^{16}$

When applied to the prevailing conditions of the Grand Duchy of Finland, however, the nationalist programme based on the principle of ethnicity faced considerable challenges. Not only was 
Finland a part of the multiethnic Russian Empire but it also had indigenous ethnic minorities (the Sámi people and the Romani people) and the bilingual majority population, divided into the Finnish- and the Swedish-speakers (at the end of the nineteenth century, some 85 percent and 15 percent, respectively). While the indigenous ethnic minorities were without any political or economic influence, and the ethnic immigrant groups from Russia (Jews, Tatars) extremely small, the harsh power struggle for the cultural and, therefore, political leading position was carried out by the Finnish-language camp, the Fennomans, and the Swedish-language camp, the Svecomans. The language struggle was fuelled by the fact that Swedish was the mother tongue of the upper echelons of society, whereas the huge majority of the Finnish-speaking common people were without political rights until the 1906 parliamentary reform. Therefore the Fennomans, many of whom were originally native Swedish-speakers belonging to the emerging educated middle classes, insisted that the unification of Finns as a "real nation with one language and one mind", able to withstand Russian pressure, was possible only if the educated classes chose to change their linguistic and cultural identity from Swedish to Finnish. By finnicising their identity, the Fennoman activists also aimed at establishing themselves as the mouthpieces of "the will of the people" and its "natural" leaders, thus politicising the concept of "the people" (kansa, folk). The process resulted in the ethnogenesis of Finnish nationalism, in which the Fennomans and the Svecomans started to understand themselves as ethnically distinct from each other, divided into the Finnish-speaking Finno-Ugrians and the Swedish-speaking Germanic nation. Moreover, the process tended towards the nationalisation and ethnicisation of class conflicts, intensified by the social turmoil of the first globalisation period of the modern capitalist economy from the 1870s onwards. ${ }^{17}$

\section{The Lamprechtian Kulturgeschichte in Finland}

In the light of the above-mentioned cultural and political struggle, it presumably comes as no surprise that the early interest in social history and mass phenomena in Finland arose among those historians whose ideological background was in the Fennoman movement. For them, Karl Lamprecht's Kulturgeschichte, with its nomothetic approach focused on the substratum of economy, society and culture, was nothing new. On the contrary, this "total history" fitted in well with the existing idea of the Kulturnation founded on language, society and culture. Furthermore, it seemed to offer the means to gain knowledge that could be used as a basis for social policy reforms, central to the Fennoman politicians who legitimised their power position by acting as the representatives of "the Finnish people". While almost all leading historians, similar to many other European countries, were politically active, the boundaries between government machinery, the academe and civil society were blurred, and the same persons busied themselves in all sectors. An example was the Finnish Society of National Economics (Kansantaloudellinen Yhdistys), founded in 1884 on the model of the German Verein für Socialpolitik (1873). It was led by professors of history who also served as senators in the senate of Finland, the grand duchy's highest governing body. Moreover, because of the undifferentiated character of the Finnish academic world and the academic disciplines in general, the same persons smoothly crossed the borders of various disciplines, such as history, sociology, social policy, national economics and political sciences. For instance, the Lamprechtian historians K.R. Brotherus (1880-1949) and 
Ernst Nevanlinna (1873-1932) later became professors of political science and national economics, respectively. ${ }^{18}$

Of the first generation of Finnish Lamprechtians, Gunnar Suolahti (formerly Palander, 18761933) and Väinö Voionmaa (formerly Wallin, 1869-1949) made a lifelong career in history. ${ }^{19}$ Suolahti specialised in the social history of the "Finnish" gentry in the early modern period, ${ }^{20}$ focusing on its socioeconomic stratification, social mobility, livelihood, interests and mentality, understood as a sort of "social psyche" shaped by the social milieu in its totality. For him, of special interest was the question of the emergence of modern individuality, somewhat paradoxically considered as a collective phenomenon, out of the constraints created by traditional society. ${ }^{21}$ Voionmaa, for his part, was more interested in the rural population and the formation of the Finnish working class by the spread of waged labour and capitalist industrialism, which for him was intimately linked with the process of democratisation. According to Voionmaa, the basic tension of modern capitalist society was the conflict between class division and the principle of equality, in other words, plutocracy versus democracy. ${ }^{22}$ Although neither Suolahti nor Voionmaa was an uncritical follower of Lamprecht, the collectivist approach was something that they both had in common. Thus, instead of great leaders, political events and administrative decision-making, they concentrated on long-term social, economic and cultural structures and changes. As Suolahti put it in 1905, in this type of history writing, the individual was merely seen as "a fragment of the oscillating life of his/her time, emerging from it and merging into it; a result of temporal development - and nothing else". ${ }^{23}$

It might be an exaggeration to say that there was such a thing as "the Finnish Methodenstreit", for due to the influence of the Fennoman movement a significant group of historians greeted Lamprechtian impulses with a favourable response. This does not mean, however, that it was unanimously praised. Firstly, Lamprechtian collectivism was connected to a broader debate on the philosophy of history, focused on the relation of particularity to universality, and, as its political dimension, on the ongoing struggle between the idealistic and materialist conceptions of history. According to the idealistic critics of Lamprechtianism, many of them philosophers or literary scholars, the collectivist approach, which explained behaviour by means of socioeconomic structures, left no room for human uniqueness ("the soul") or free will. Thereby it ultimately made individual ethical responsibility impossible. Similarly to other "dangerous" currents of the time, such as Nietzschean cultural radicalism and Marxist socialism, it was blamed for leading to unrestricted relativism without a horizon of transcendental, absolute values. ${ }^{24}$

Secondly, Lamprechtianism was rejected by the Swedish-speaking Svecoman historians. In this case, the controversy was inherently related to the debate about which area of historiography should be accorded the central place in explaining historical events, and which spheres should be considered structurally and causally fundamental. In the eyes of the Svecoman camp, the Finnish Lamprechtians' dismissal of political actors, military leaders and other great individuals was politically, not scholarly, motivated, for it allowed the masses of ordinary Finnish-speaking people to step forward into the limelight of historical interest as actors of the utmost importance. Therefore, it seemed to sanctify the teleological conception of Finnish history, in which the progress of Fennoman ethnic nationalism became inevitable, dictated by irresistible histori- 
cal forces. As a counterreaction, the Svecomans emphasised Finland's historical relation to the Swedish Empire, insisting that there was no separate "history of Finland" before 1809. Moreover, as the defence of scientific objectivity against the ethnicisation of Finnish history, in which the Swedish-speaking elites were described as "unnational foreigners", they laid stress on the minutiae of archival scholarship, based on a positivist craftsman's ideology of historical research with little room for questions on the ontology, epistemology or metatheories of history and society. ${ }^{25}$ On reflection, however, their descriptive studies on state actions, institutions and influential personalities were also ideologically biased, even the reformist Svecoman perspective was predominantly a "top-down" one, and ordinary people merely played the role of passive objects. Similarly, historiography gave full historical agency only to the upper echelons of society, and thus implicitly reinforced the ordinary people's prevailing subalternity. ${ }^{26}$

Finally, the battle line between the Fennomans and the Svecomans was blurred by the fact that there was also a group of ardent Fennoman historians who, nevertheless, objected to the collectivist approach. The leader of this fraction was the historian Arno Rafael Cederberg (1885-1948), the first professor of Estonian and Nordic history at the University of Tartu, Estonia, in 1919. In Cederberg's case, the objection to Lamprechtianism had developed into a strong personal dislike for Gunnar Suolahti, which in its intensity came close to the German assault against Karl Lamprecht. ${ }^{27}$ According to Cederberg, Suolahti, in his position as university professor, had nearly ruined a whole generation of future Finnish historians by encouraging them to make "irresponsible generalisations" and to focus on typical, large-scale social phenomena, thus neglecting the factual accuracy and the detailed reflection of first-hand sources. For Cederberg, the motor of historical development was located in the great personalities through whom history made progress. In his case, however, contrary to the Svecoman camp, the emphasis on individuals did not necessarily lead to an elitist perspective, for he was also fascinated by courageous, heroic common men of the past. ${ }^{28}$ To sum up, while the Lamprechtian historians emphasised the power of the masses, Cederberg wanted to elevate prominent ethnically Finnish persons to crucial positions in the national history, regardless of their social class.

\section{The ideological and political role of Lamprechtianism}

In the Finnish history of historiography, early Lamprechtian social historians have often been acclaimed as bold reformers who successfully challenged the narrowly factual positivist approach and the antidemocratic political bias of the established historical scholarship, thus contributing to the advancement of the historical discipline and the democratisation of Finnish society. ${ }^{29}$ In the following discussion, it is not my intention to deny this conception, for there is no reason to contest the groundbreaking role of the Lamprechtians. This, however, does not undo the fact that there were also other dimensions in their work that cannot be unambiguously considered as "progressive" and "democratic". I will, therefore, at the end of this article, briefly discuss some of these ideological and political features which, from a crossnational comparative perspective, can be considered typical of national narratives trying to come to terms with the potentially contradictory concepts of "class", "people" and "nation". ${ }^{30}$ Moreover, they also suggest how intimately the formation of national narratives and nation-building in Europe was connected with 
imperialism and colonial rule. ${ }^{31}$ As an example, I will use Väinö Voionmaa's works that clearly illustrate the case.

In Finland, Voionmaa's three-volume study (1903-1910) on the history of the city of Tampere, the major industrial town of the country, was the first extensive historiographical study that aimed at analysing the breakthrough of the modern industrial capitalist system from the viewpoint of the social classes and their mutual relations. For Voionmaa, the history of Tampere provided an opportunity to study the formation of the modern working class, its historical emergence from certain groups of manual labourers and craftsmen, and their gradual transformation into modern wageworkers and the proletariat. In this work, similar to his edited two-volume work on the history of social democracy in Europe $(1906,1909)$, he promoted the Marxist-based idea that in modern industrial society, the emancipation of the working class was inevitable because of the new mode of production and the intensifying struggle between labour and capital caused by this mode. "The working class movement had to advance, socialism had to be born," Voionmaa stated in 1909.32

However, despite his Marxist-based conception of class and society and his openly leftist political sympathies, Voionmaa joined the Finnish Social Democratic Party only in 1918, when after the devastating Finnish Civil War the party had clearly rejected the doctrine of Marxist class struggle and adopted the reformist, revisionist conception of socialism. For him, socialism was, above all, a movement pleading the case of inner self-formation (in Finnish, sivistys, in German, Bildung), ${ }^{33}$ and social ethics that were based on the principles of equality and justice. Emblematic of this thinking was the fact that he had initially become acquainted with working-class activists in the temperance movement where the (self-) educational dimension of popular mobilisation was strongly emphasised. ${ }^{34}$ It is thus no surprise to notice that in the case of Voionmaa, social class clearly played the role of a subdiscourse to the national master narrative rather than that of a counterdiscourse which, with an international revolutionary content, could have threatened the Finnish nation's integrity. The concepts of "the working class" and "the people" thus became interchangeable, the main issue being the integration of the working class into the Finnish nation. ${ }^{35}$

In this respect, the scholarly focus on the long-term changes in socioeconomic structures can be interpreted as having had an ideological role, for it implicitly suggested the beneficent consequences and historical importance of continuous evolution in contrast to radical ruptures, discontinuity and revolution. Indeed, the stronger the pressure from Russia (from 1917 onwards, Bolshevik Soviet Russia) and the Marxist working-class movement on the national unity of Finland, the stronger the academic historians' emphasis on the necessity of a "proper" historical worldview, based on an idea of steady, evolutionary continuity. ${ }^{36}$ When one takes into account that at the beginning of the twentieth century some 75 percent of the students who took their master's degree from the arts faculty of the University of Helsinki had history as a major or minor subject, ${ }^{37}$ historical knowledge could be efficiently used in legitimating a certain political order among the whole age group of the future cultural elite.

As an example of the explicitly political use of historiography, one can take Voionmaa's Suomen uusi asema [The new position of Finland], published in 1919 after the collapse of the Russian 
Empire but before the signing of the Treaty of Tartu (1920) that confirmed the border between Finland and Soviet Russia. In this book, aimed at popular enlightenment, Voionmaa utilised the Lamprechtian perspective of socioeconomic "total history" and the geopolitical ideas of the German geographer Friedrich Ratzel (1844-1904), Lamprecht's colleague and scientific inspiration, in his discussion on territorial politics. On the one hand, Voionmaa admitted that the borders had always been contested and shifting, because from the European perspective, Finland belonged to "the precarious zone" between the East and the West which ran from the Balkan Peninsula along the Danube and the Vistula all the way to the Baltic countries, Lapland and the Arctic Ocean. On the other hand, however, according to Voionmaa, the Finnic peoples ${ }^{38}$ themselves comprised an ethnic mesoregion, a totality of economic, social, cultural and geographic characteristics which taken together defined "Finland's natural borders". At the core of this discussion was Eastern Karelia, the peripheral borderland between Finland and Soviet Russia, which, for the most part of its written history, had been a part of the Russian Empire but which, in the light of these "clear-cut natural borders", actually belonged to "Greater Finland", cherished by the preSecond World War pan-Finnicism.

With Voionmaa's discussion on the justified expansion of Finland, one is brought back to the political dimension of the Herderian Kulturnation, for in his case, Finnish expansionism was legitimatised by the concept of "sivistys" (Bildung), a crucial concept in Herder's philosophy, too. In Voionmaa's vision, among the Finnic peoples, the Finns had achieved the highest level in the process of self-formation (Bildungsprozeß), which entitled them to incorporate Eastern Karelia into the independent state of Finland in order to elevate the Karelians into a Kulturnation. Similar to his conception of socialism, he emphasised here the replacement of force by culture. As neighbours to the powerful Soviet Russia, the Finnic peoples could, he assumed, defend their right to existence only by peaceful means and inner civilisational strength. ${ }^{39}$ Nevertheless, and typically for the colonialist rhetoric of the time, the Finnish conquest of Eastern Karelia was presented as the benevolent development of that peripheral, backward "dark corner" of Europe in order to guarantee it the civilisational achievements already reached by Western Europe. In all, this rhetoric manifested the power of colonialist thinking in the postimperial European small-states among the reformers who, as in the case of the Finnish Lamprechtians, merely saw themselves as the victims of colonial oppression by the old empires of Eurasia. 


\section{NOTES}

1 Gina Deneckere and Thomas Welskopp, “The 'Nation' and 'Class': European National Master Narratives and Their Social 'Other'”, in Stefan Berger and Chris Lorenz (eds), The Contested Nation: Ethnicity, Class, Religion and Gender in National Histories, New York: Palgrave Macmillan, 2008, 150.

2 See also Peter Aronsson, Narve Fulsås, Pertti Haapala and Bernard Eric Jensen, "Nordic National Histories", in Berger and Lorenz (eds), The Contested Nation, 256-282.

3 In terms of present academic subfields of history, Lamprechtian Kulturgeschichte mostly covers the fields of cultural history, social history and economic history. In this article, the German concept of Kulturgeschichte is used to refer specifically to Karl Lamprecht's sociocultural history school.

4 In the context of national culture and nation-building, see, for example, Frederik M. Barnard, "National Culture and Political Legitimacy: Herder and Rousseau", Journal of the History of Ideas 44/2 (1983), 249.

5 For the conceptions of "politics" and "politicisation", see Kari Palonen, "Introduction: From Policy and Polity to Politicking and Politicization", in Kari Palonen and Tuija Parvikko (eds), Reading the Political: Exploring the Margins of Politics, Helsinki: The Finnish Political Science Association, 1993, 11-13.

6 For the conception of ideology, see Karl Mannheim, Ideology and Utopia, London: Routledge and Kegan Paul, 1936; Raymond Williams, Keywords: A Vocabulary of Culture and Society, London: Fontana, 1983, 153-157; see also Peter Burke, History and Social Theory, 2nd ed., Cambridge: Polity, 2005, 98-99.

7 On a theoretical level, see, for example, Bo Stråth, "Historiography, Social Sciences, and the Master Narratives", in Q. Edward Wang and Franz L. Fillafer (eds), The Many Faces of Clio: Cross-cultural Approaches to Historiography, New York and Oxford: Berghahn, 2007, 128-129, 135-136; Keith Jenkins, Re-thinking History, London and New York: Routledge, 2003, 82-83.

8 Väinö Voionmaa, "Tampereen kaupungin historia: Tuloksia ja kokemuksia" [The history of the city of Tampere: Some results and experiences], Historiallinen Aikakauskirja 5 (1911), 349-350. All citations from Finnish into English have been translated by the author.

9 Max Engman, "National Conceptions of History in Finland", in Erik Lönnroth, Karl Molin and Ragnar Björk (eds), Conceptions of National History, Berlin and New York: Walter de Gruyter, 1994, 49-51.

10 Johan Jakob Tengström, “Om några Hinder för Finlands Litteratur och Cultur I-II” [About some constraints on Finland's literature and culture I-II], in Aura, first part in 1817, second part in 1818, 72-73.

11 Johan Jakob Tengström, "Paragrapher ur Finlands Forntid" [Paragraphs about Finland's antiquity], Helsingfors Morgonblad 71-74 (1835); Zachris Topelius, “Äger finska folket en historie?" [Do the Finnish people have a history?] Joukahainen 2 (1845), 189-247; see also Matti Viikari, "Die Tradition der finnischen Geschichtsschreibung und Karl Lamprecht”, Storia della storiografia 6 (1984), 35-37.

12 See, for example, Engman, 50-53.

13 Barnard, 245-246, 250-251; see also Joep Leerssen, “Nation and Ethnicity”, in Berger and Lorenz (eds), 75-103.

14 Johan Vilhelm Snellman, Samlade arbeten III, Helsingfors: Statsrådets kansli, 1993, 491.

15 Johan Vilhelm Snellman, Samlade arbeten IV, Helsingfors: Statsrådets kansli, 1994, 16-18, 32-33.

16 See, for example, Marja Jalava, Minä ja maailmanhenki: Moderni subjekti kristillis-idealistisessa kansallisajattelussa ja Rolf Lagerborgin kulttuuriradikalismissa n. 1800-1914 [Self and the spirit: The modern subject in Christian idealistic nationalism and Rolf Lagerborg's cultural radicalism in Finland, 
c. 1800-1914], (= Bibliotheca Historica 98), Helsinki: SKS, 2005, 156-157.

17 For the language struggle in Finland, see, for example, Engman, 49-50; Ilkka Liikanen, "The Ironies of People's Power", in Lars-Folke Landgrén and Pirkko Hautamäki (eds), People, Citizen, Nation, Helsinki: Renvall Institute, 2005, 74-89; for the ethnicisation of class concepts in the western borderlands of the Russian Empire, see Anna Veronika Wendland, "The Russian Empire and its Western Borderlands: National Historiographies and Their 'Others' in Russia, the Baltics and the Ukraine”, in Berger and Lorenz (eds), 418.

18 Leo Harmaja, Kansantaloudellinen Yhdistys 1884-1934 [The Society of National Economics, 18841934], Helsinki: Otava, 1934, 51-52, 144-146; Pertti Haapala, "Muotia vai ei? - Suomalaisen sosiaalihistorian muuttuvat näkökulmat." [Fashion or not? The changing viewpoints of Finnish social history], in Kyösti Kiuasmaa et al. (eds), Yksilö ja yhteiskunnan muutos [Individual and social change], (= Acta Universitatis Tamperensis Ser A 202), Tampere: Tampereen yliopisto, 1986, 265-267.

19 In order to emphasise their linguistic and cultural Finnish identity, Suolahti and Voionmaa finnicised their previously Swedish surnames in 1906.

20 In this context, the word "Finnish" refers to that part of the Swedish gentry who had lived in the area of the future Finland.

21 See, for example, Gunnar Palander (Suolahti), “Valistuskauden sielunelämää” [On mental life during the Age of Enlightenment], Historiallinen Aikakauskirja 1 (1905), 15-22 and 5 (1905), 160-169.

22 For example, Väinö Voionmaa, Tampereen kaupungin historia, III osa: Tampereen historia viime vuosikymmeninä (1856-1905) [The history of the city of Tampere, part 3: The history of Tampere during the latest decades, 1856-1905], Tampere: Tampereen kaupunki, 1907-1910.

23 Gunnar Palander (Suolahti), "Historiallista kirjallisuutta” [Historical literature], Historiallinen Aikakauskirja 6 (1905), 225.

24 See, for example, the Records of the Philosophical Society of Finland, 21 Nov 1903 onwards. Published in Juha Manninen and Ilkka Niiniluoto (eds), Ajatuksen laboratorio: Filosofisen Yhdistyksen pöytäkirjat 1873-1925 [The laboratory of thought: The records of the Philosophical Society, 1878-1925], Helsinki: Suomen Filosofinen Yhdistys, 1996.

25 For example, Engman, 55-56; Pekka Ahtiainen and Jukka Tervonen, Menneisyyden tutkijat ja metodien vartijat: Matka suomalaiseen historiankirjoitukseen [Researchers of the past and guardians of the methods: A journey into Finnish historiography], Helsinki: SHS, 1996, 226-228.

26 On a general level, see Eric Hobsbawm, On History, London: Abacus, 1997, 267-268.

27 Cf. Roger Chickering, Karl Lamprecht: A German Academic Life (1856-1915), New Jersey: Humanities Press, 1993.

28 See Eija Juujärvi, “Historian uupumaton työmies A.R. Cederberg - historiantutkija, arkistomatkaaja ja isänmaanystävä" [The tireless workman of history A.R. Cederberg: historian, archival voyager, and patriot], in Ari Vallius (ed.), Arno Rafael Cederberg, Joensuu: Pohjois-Karjalan Historiallinen Yhdistys, 1997, 54-64, 83-93.

29 See, for example, Ahtiainen and Tervonen, 163-165, 226-229.

30 Cf. Deneckere and Welskopp.

31 For the trajectory of the Eurasian old empires (the Habsburg, Ottoman and Romanov) into nation- 
states, see, for example, Frederick Cooper, Colonialism in Question: Theory, Knowledge, History, Berkeley and Los Angeles: University of California Press, 2005, 153-158.

32 Väinö Voionmaa, Sosialidemokratian vuosisata Il osa [The century of social democracy, part 2], Porvoo: WSOY, 1909, 525.

33 Sivistys (in German, Bildung) is a specifically German coinage used in the Lutheran-dominated, culturally German-influenced regions of northern Europe, including the Nordic countries. While it is extremely difficult to find an equivalent for it in English, it should be understood as a processual state of mind that constantly and actively changes through self-reflexivity. It is a metaconcept, referring to the never-ending process of self-formation in which the goal is included in the process itself (Bildungsprozeß); see Reinhart Koselleck, The Practice of Conceptual History: Timing History, Spacing Concepts, Stanford, CA: Stanford UP, 2002, 170-207.

34 Aimo Halila, Väinö Voionmaa, Helsinki: Tammi, 1969, 50-59.

35 Cf. Deneckere and Welskopp; see also Haapala, 266-267.

36 See, for example, Oskari Mantere, "Historian kirjoituksen ja opetuksen kysymyksiä" [Questions on history writing and teaching], Historiallinen Aikakauskirja 4 (1911), 293-294; Arvi Korhonen, "Vallankumouksellisesta ja historiallisesta katsomustavasta" [About revolutionary and historical viewpoints], Historiallinen Aikakauskirja 1 (1922), 1-39.

37 Päiviö Tommila, Suomen historiankirjoitus, Helsinki: WSOY, 1989, 99.

38 The ethnographic term "Finnic peoples" commonly includes Finns, Karelians, Estonians, Ingrians and Kvens, who are all considered to be ethnically related.

39 Väinö Voionmaa, Suomen uusi asema [The new position of Finland], Helsinki: WSOY, 1919, 370-399. 